\title{
Metonymy and Metaphor as Verbal Postulation: The Epistemic Status of Non-Literal Speech in Indian Philosophy
}

MALCOLM KEATING

Yale-NUS College, Singapore (malcolm.keating@yale-nus.edu.sg)

In this paper, I examine Kumārila Bhatta's account of figurative language in Tantravarttika 1.4.11-17, arguing that, for him, both metonymy (lakssanāa) and metaphor (gauna-vrtti) crucially involve verbal postulation (śrutârthäpatti), a knowledge-conducive cognitive process which draws connections between concepts without appeal to speaker intention, but through compositional and contextual elements. It is with the help of this cognitive process that we can come to have knowledge of what is meant by a sentence in context. In addition, the paper explores the relationship between metonymy and metaphor, the extent to which putatively literal language involves metonymy, and the objective constraints for metaphorical interpretation.

Keywords: Indian philosophy; Mīmāṃsā; philosophy of language; metaphor; epistemology; interpretation

\section{$1 \quad$ Introduction}

Roman Jakobson and Morris Halle argue in Fundamentals of Language that there are two relationships which form the foundation of language use, not only in the individual speaker, but in a wider sense, as the basis of genres such as poetry and prose. ${ }^{1}$ These relationships are similarity and contiguity, which Jakobson and Helle characterize as the basis of metaphor and metonymy, respectively, though they lament the theoretical preoccupation with metaphor in contrast to metonymy. In his 2010 lecture to Harvard University, Sanskritist and linguist Edwin Gerow suggests that Indian philosophy should force us to re-examine the thesis of this now-classic paper. Demonstrating that the twin poles of metaphor and metonymy were well-established in Indian poetics and philosophy, Gerow observes that, in contrast to the predominance of metaphor in Western thought, Indian linguistic analysis has theories focusing strongly on metonymy. He argues that their emphasis on the objective nature of figurative language is "unparalleled and deserves to be noted in any account of theories of language." 2

Gerow is correct, and in this paper, I focus on the basis of this objective nature in the Mīmāmsāa or "Hermeneutics" tradition of Indian philosophical thought, in particular the work of seventh century CE thinker Kumārila Bhațta. ${ }^{3}$ For Kumārila, linguistic interpretation involves a cognitive process which draws connections between concepts without appeal to speaker intention, but through compositional and contextual elements, and by which we can come to have knowledge of what is meant by a sentence in context. This cognitive process is knowledge-conducive - thus having an objective nature as Gerow suggests—and underwrites metonymy and metaphor, which turn out to be pervasive in language.

One ordinary example will illustrate these two phenomena. Suppose I were to say about my morning cup of coffee,

Journal of World Philosophies 2 (Summer 2017): 67-80

Copyright (C) 2017 Malcolm Keating.

e-ISSN: 2474-1795 • http://scholarworks.iu.edu/iupjournals/index.php/jwp• doi: 10.2979/jourworlphil.2.1.06 
(1) That cup is the starting-bell for my day.

The sentence uttered involves both metonymy and metaphor. "Cup" refers not just to the ceramic mug in which I keep my coffee, but also to the liquid contained within it. This is metonymy. Very broadly, metonymy is when the ordinary referent of a word is expanded to include another referent which is related to it appropriately, such as by close proximity, ordinary association, cause-and-effect relations, and so on. Metaphorically, the coffee (or, strictly, the effects of the coffee) is then understood to be something which prompts the start of my day, like the bell that starts trade at the New York Stock Exchange. Metaphor may be even harder to define initially than metonymy, but we might say it is the identification of two dissimilar things, often across categories, such as identifying living beings with inanimate things (the now-conventional "Juliet is the sun.")

Understanding the relationship between metonymy and metaphor, and how hearers understand what is meant by an utterance employing them, has implications for our theorizing about word meaning, the relationship between literal and non-literal speech, and how world knowledge is implicated in linguistic competence. ${ }^{4}$ One question we can ask about metonymy and metaphor is how a hearer shifts from a literal referent for "cup" to one which includes the coffee, or draws a connection between coffee and starting-bells. Another question we might ask is how pervasive metonymy and metaphor are in ordinary speech. In response to the first question I argue that the epistemic process known as "verbal postulation" ('sruta-arthapatti), as described by the Indian philosopher Kumārila Bhatța, is involved. In response to the second question, I demonstrate that both metonymy and metaphor are widely involved in linguistic interpretation.

Verbal postulation is taken by Kumārila and others to be a pramana, or a source of knowledge. Pramanas are psychological processes whose correct operation yields an occurrent mental state constituting knowledge. Perception (pratyaksa) and inferential reasoning (anumana) are two of the most commonly accepted sources of knowledge. Philosophical schools differed over how to characterize pramanas as well as which are reducible to others (for instance, is testimony reducible to inference?). Kumārila argues that verbal postulation is an irreducible pramana. I explicate his account of verbal postulation in terms of reliance upon objective linguistic norms and structural relationships within concepts. I show how Kumārila explains metonymical comprehension as based on verbal postulation, and how metonymy is foundational for utterance comprehension whether in a figurative or literal context. ${ }^{5}$

I also argue that Kumārila's understanding of metaphor likewise relies upon verbal postulation. This puts him in a position to explain how linguistic interpretation can acquire the status of knowledge. Ordinarily, we might think that metaphorical interpretations are defeasible, open-ended, and do not constitute knowledge. However, Kumārila shows how, through verbal postulation, it is possible (in certain cases) to gain knowledge of a particular, definite cognitive structure which is the meaning of a metaphor.

\section{$2 \quad$ Verbal Postulation}

Kumārila defines postulation generally in his Commentary in Verse (Sloka-värttika or SV), distinguishing between two kinds of postulation, verbal (srutah) and experiential (drstabs): ${ }^{6}$

Now, postulation is when an object experienced or heard is not explicable otherwise; therefore an(other) object is presumed. ${ }^{7}$

Journal of World Philosophies 2 (Summer 2017): 67-80 
Kumārila gives a number of examples of postulation, such as postulating that someone is outside from seeing that they are not inside their home ( $\$$ V 5.8, Jha 2009: 595ff). Roughly, postulation functions on a piece of knowledge from one epistemic source-such as perception or inference-drawing a conclusion which is necessary in order to make sense of that original bit of knowledge. More precisely, an inexplicability arises because a newly experienced or heard object of knowledge is in apparent conflict with another, already-accepted piece of knowledge. A resolution is determined by conceptual connections, although I argue below that the degree to which these connections are informed by lexical knowledge or contextual information is variable. This schema represents how verbal (not experiential) postulation functions: ${ }^{8}$

Verbal Postulation ' $q$ ' is postulated from ' $p$ ' and $m$ iff:

1. ' $p$ ' is an utterance known via testimony and $\mathrm{m}$ is an already-established fact.

2. The presumption of ' $q$ ' is required to make ' $p$ ' compatible with $m$.

This schema makes explicit that there must be an incompatibility between the linguistically given piece of knowledge (' $p$ '), which is known through the pramana of testimony, and some other thing which is already known, $m$. Precisely what $m$ is will vary, I argue, depending on the case of verbal postulation, but it must broadly involve a set of objective, intersubjectively available norms about linguistic communication.

Kumārila takes there to be two kinds of postulation, corresponding to the two ways of understanding the first object of knowledge: experience or testimony. "Experience" encompasses all epistemic sources or pramana apart from testimony, which is the sole epistemic source for postulation based on what is heard, or verbal postulation. The paradigmatic case of verbal postulation is:

(2) a. Fat Devadatta does not eat during the day.

b. Devadatta eats at night.

From (2a), one will postulate and thereby come to know (2b). What causes verbal postulation, and why is the content of our postulation Devadatta's eating at night (rather than, anachronistically, his drinking protein shakes during the day)? Kumārila explains things as follows:

Therefore, with regard to the heard sentence ['Fat Devadatta does not eat during the day'], there would be no arising of its conveyed meaning, without [postulation]. This is what is correct. ${ }^{?}$

Pārthasārathi Miśra, a later commentator (c.1075 CE) on SV, remarks on this explanation:

As fatness and the negation of eating are impossible as a unified sentence meaning (eka-vakya), there is posited the sentence about night as a supplied phrase for the cause [of the fatness]. ${ }^{10}$

The idea is that this uttered sentence cannot deny a cause to fatness since it is part of the conceptual structure of fatness that it has a cause. It would violate our understanding of how the word "fat" is used to deny a cause. Such denial would flout the standard requirement that sentences have appropriate semantic connections between words, or yogyata. Therefore, we have to assert some cause. Applying the schema to the case of Devadatta, we might characterize verbal postulation this way:

Verbal Postulation in the Case of "Devadatta"

Journal of World Philosophies 2 (Summer 2017): 67-80 
'Devadatta eats at night' is postulated from 'Fat Devadatta does not eat during the day' and the requirement that sentences must be unified meaningful entities iff:

1. 'Fat Devadatta does not eat during the day' is an utterance known via testimony and that sentences must be unified meaningful entities is an already-established fact

2. The presumption of 'Devadatta eats at night' is required to make 'Fat Devadatta does not eat during the day' compatible with the requirement that sentences must be unified meaningful entities.

Here, verbal postulation results in our coming to understand an additional sentence, "Devadatta eats at night." Kumārila is very clear that this new sentence is not part of the original sentence-meaning (though he says that others might wish to argue this), since it is not meant by any of the words in the sentence (Jha 2009: 641). Another meaning is, we might say with H.P. Grice, implicated, from the ordinary meaning (sva-artha, natural or own-meaning) of the sentence. Where Kumārila argues that the sentence as uttered cannot be understood as meaningfully unified, the kind of unity he is considering must be a functional one. In other words, while there is nothing syntactically wrong with the sentence, it does not make sense to utter given what we know about the concept of fatness.

The meaning of this postulated expression is determined based on what would make the utterance make sense, says Kumārila. We might think that there are multiple ways to "repair" the sense, however. Perhaps we could postulate, "Devadatta drinks during the day." This is excluded, though, because the assumption is that it is eating (and not drinking protein shakes) which is the cause of fatness. Given this, if eating during the day is out of the question, only eating at night is explanatorily possible. While this kind of reasoning has been characterized as deductively necessary semantic implication (Yoshimizu 2007), it is important to recognize that, as described here, this process involves an apparent incompatibility. This is a feature which straightforward deductive reasoning lacks. This apparent incompatibility is crucial to verbal postulation and, as we will see, to how it is involved in other aspects of linguistic understanding.

\section{$3 \quad$ Linguistic Interpretation: Metonymy}

Kumārila also understands metonymical linguistic interpretation as functioning through verbal postulation. There are two lines of evidence for this: the words of Kumārila himself and texts remarking on him. ${ }^{11}$ The second set of evidence is sketched out in Raja (1994), and is not the primary concern here. The evidence in Kumārila comes in his treatment of ordinary sentence meaning as well as figurative sentences. Raja (1994: 104) puts the general point clearly:

And laksañā [metonymy] involves a kind of arthäpatti pramāna [verbal postulation knowledge source] as accepted by the Bhāțta Mīmāmsakas. To reconcile two known facts-the primary meaning of the word known through remembrance, and the general purport of the sentence known through contextual factors, a meaning which is related to the primary meaning and which is capable of removing the apparent conflict is resorted to in this case. ${ }^{12}$

In the $S V$ chapter on sentence meaning, Kumārila develops the Bhātța Mīmāṃsā view of sentence meaning against competing theories, taking care to explain how it is that sentences come to be unified semantic and syntactic entities, rather than simply a string of words. In brief, the manner in which uttered sentences convey meaningful content is through a combination of word-meanings in dependence upon the main action 
of the sentence. According to Kumārila, the purpose of a meaning is to convey an action, so all of the words in the sentence must be related to the verb. For Kumārila, words have only a single primary meaning-the universal class property for nouns and, for adjectives, a quality. ${ }^{13}$ Words in a sentence would only be a list of these meanings, unless they are unified into a single structure. So, for instance, saying

(3) Bring the white cow

requires the primary meanings of "cow" and "white" to be connected to the action of bringing.

However, universal class properties are not bearers of qualities (saying cowhood is white is nonsensical) and neither would one bring cowhood on its own. Thus Kumārila says that there is a mutual exclusion (avacchedab) of the words in combination which coerces a shift from a universal to an individual cow, which is qualified by whiteness (Jha 2009: 1284, Aphorism 24 to 26, verses 267 to 271). This mutual exclusion process is due to metonymy.

Kumärila makes this connection explicit in explaining the knowledge-producing function of Vedic language in his Commentary on the Ritual System (Tantra-varttika, or TV). Kumärila's thesis is that a particular utterance is metaphorical, not metonymical:

(4) The ritual grass-bed is the ritual patron.

This sentence, like many stock examples in Mīmāmsāa, is related to Vedic rituals, in this case the New and Full Moon Ritual. ${ }^{14}$ To show that this is a case of metaphor and not metonymy, he defines the difference between the two:

"Metonymy" (laksaña) is said to be the function occurring when there is inseparability with what is expressed; in contrast, by "metaphor" (gaunata) is meant the function from connection with qualities being indicated. ${ }^{15}$

To illustrate metonymy, Kumārila gives several examples, one of which is quite close to the sentence we saw from the SV:

[...] just as a word which directly expresses a universal class property metonymically indicates the particular which accompanies that form, in the same way, there are metonymically indicated meanings of the people who are connected with "staffs," "platforms," "horses" and so on. ${ }^{16}$

Here, he refers to several stock sentences:

(5) The staffs are to be ushered in.

(6) The platforms cry out.

(7) The king is conquered by one thousand horses. ${ }^{17}$

The words are indicating (5) by "staffs," people carrying staffs, (6) by "platforms," people sitting on high "platforms" (possibly tall wooden structures where a lookout is stationed, although an early variant in the Maha-bhassya refers to theatre benches) calling out a warning, (7) by "horses," warriors riding on horses. Although the words directly, literally mean staffs, platforms, and horses, each of these objects is accompanied by a person, and it is the person that is being indicated. Further, the metonymical meaning becomes part of the 
entire sentence meaning. We might fill out what is meant by (5) in this way: "The [people carrying the] staffs are to be ushered in." Kumärila notes that metonymy happens in these three cases just as (yathāa) a word denotes a universal class property, or a class, but metonymically indicates the particular thing which accompanies the form. So, for instance, in the sentence

(8) A cow is to be tied up

on Kumārila's view, the literal meaning of the word "cow" is COWHOOD (words in small caps represent universals), but because COWHOOD always is associated with-and in fact, for the Mimämsā, identical with-an individual (universals are not free-floating), we understand that a cow is meant. After all, COWHOOD does not wander around on its own, but it is always associated with a particular, through the specific relationship of inherence.

Put in terms of the Devadatta sentence above, the sentence meaning would be "inexplicable otherwise" (anyatha-anupapattibi) if a particular were not postulated as the meaning of the word in the context of a sentence:

Verbal Postulation in the Case of "Cow"

'The individual cow is to be tied up' is postulated from 'The cow [COWHOOD] is to be tied up' and the requirement that sentences must be unified syntactic and semantic entities iff:

1. 'The cow [COWHOOD] is to be tied up' is a utterance known via testimony and the requirement that sentences must be unified syntactic and semantic entities is an already-established fact

2. The presumption of 'The individual cow is to be tied up' is required to make 'The cow [COWHOOD] is to be tied up' compatible with the requirement that sentences must be unified syntactic and semantic entities.

I have already argued that this case fits with a particular model within contemporary linguistics, sortshifting which can possibly explain cases of metonymy of this kind, discussed by a later Indian philosopher, Mukula Bhatta. ${ }^{18}$ Underlying this account is the insight that our lexical entries for words act as miniature theories of the world, and contain information such as what kind of thing something is, what it is used for, what its structure is, and so on. In combination with other words, these lexical entries interact to coerce "shifts" in meaning. While this meaning shift may not be present to conscious awareness, since language-processing is rapid, it is performed in order to resolve a conceptual tension.

This new meaning is generated by appealing to the conceptual structure of the lexical entry. Kumārila hints at this kind of lexical structure in the TV, where he says, 'On uttering the word 'cow,' there are seven things manifest to us: The universal and individual, the relation (between them), the collection (of all three), gender and kāraka. And number is the seventh." ${ }^{19}$ He does not mean that each of these things is understood as being meant by the word (he explicitly states this in what follows), but rather that any of these elements could be manifested or brought to mind (pratibhä).$^{20}$ Because a universal inheres in a particular (relation, or sambandhah. also being part of the structure identified by Kumārila), the meaning of "cow" as an individual is easily accessible and justified as a way for hearers to understand the speaker's unified sentence meaning.

Like the case of the cow being tied up, the example (5) "The staffs are to be ushered in" involves metonymy. What "staffs" refers to is not simply a staff but rather "people (brahmins) who are carrying staffs." 21 Similarly, we might think that our understanding of the term "staffs" includes the fact of its being an artifact or an instrument, its being used by a person, purpose, and the like. Verbal postulation works within this structure here to identify and resolve an apparent contradiction. Like the previous case, too, there is something faulty about this sentence. The Sanskrit term pravésaya, "to be ushered" is one which cannot literally be applied to 
staffs, since it connotes something entering or being admitted on its own ability. And it is part of what a staff is (an instrument used by people) that it is incompatible with its walking on its own.

Likewise, in the other cases which Kumārila identifies- the platforms which cry out (inanimate objects which make sounds) and the horses which conquer a king (animals acting in a human manner) - there is an obstacle to taking them literally. What makes these cases different from the case of the cow being tied up, however, is that the process requires a further conceptual connection. For instance, if "horses" denotes, by its primary meaning, the universal (HORSEHOOD) before the person riding the horse can be accessed, there should be the postulation that particular horses, not simply their universals, are meant. This is not out of the question for Kumärila's understanding of postulation, since postulation is among the knowledge sources he identifies as being bases for the experienced variety (alongside of perception, inference, analogy, and the like). Further, since the output of verbal postulation is linguistic (sometimes words, sometimes sentences), it is plausible that this kind of iterative postulation could still be characterized as verbal postulation, working as it is with a bit of language.

\section{$4 \quad$ Linguistic Interpretation: Metaphor}

Metaphor works slightly differently, and it is metaphor that is involved in the sentence Kumärila is focused on (4) "The ritual grass-bed is the ritual patron." He also discusses two other examples of metaphor in this section of the $T V$, which illuminate the relationship between verbal postulation, metonymy, and metaphor.

(9) The young Brahmin is fire.

(10) Devadatta is a lion. ${ }^{22}$

Kumārila uses the first example to draw the contrast between metonymy and metaphor. He says,

However, in "The young Brahmin is fire," the young Brahmin is not conveyed as being necessarily related to fire, but rather, that which has a bright color and so on is understood from the meaning, fire. Through this, an understanding of the student arises due to similarity. ${ }^{23}$

In this sentence, "fire" means FIREHOOD, or the universal class property of fire. What it is to be fire is to have a bright color and other properties, represented by the equivalent of "et cetera" in the text (adi). So there is first denoted the universal class property, and then, through metonymy, the understanding of the properties belonging to that form. Finally, an understanding of the student is gotten through his being similar to the qualities of fire. Now, this cannot be the full story, since even if the student is bright, he is not bright in the same way as a fire is-visually glowing. There must be an additional step which allows us to understand the property in a metaphorical sense. This is taken up further by the Buddhist philosopher Sthiramati in his commentary on Vasubandhu's Trimsík $\bar{a}$ (in regard to this particular example, even) but not in Kumārila (Raja 1994: 244). This observation, that the qualities metonymically indicated cannot be taken straightforwardly as those in the metaphorical target, applies, ceteris paribus, to the cases which follow.

After explaining the simple example of "The young Brahmin is fire," Kumārila moves on to the problem of exhortative sentences. Omitting some technical details, his general argument is that the sentence (4) "The ritual grass-bed is the ritual patron" must be taken as metaphor on pain of absurdity. The use of the sentence in the ritual context would not be explicable otherwise (anyatha-anupapatti). He reasons as follows: if we take the identification between the ritual patron and the ritual grass-bed literally, we are faced with a problem

Journal of World Philosophies 2 (Summer 2017): 67-80

Copyright (C) 2017 Malcolm Keating.

e-ISSN: 2474-1795 • http://scholarworks.iu.edu/iupjournals/index.php/jwp• doi: 10.2979/jourworlphil.2.1.06 
at a later point in the procedure, when we are to toss the grass-bed into the fire. Since the ritual patron is supposed to attain the benefits of the ritual, if we throw him into the fire, the whole purpose of the ritual would be pointless, since it would be interrupted (vilopa). ${ }^{24}$ There is no mention of a universal as the meaning of "ritual grass-bed," but the grass-bed's quality of having a primary role in the ritual is the quality which the ritual patron shares through similarity. ${ }^{25}$ Kumärila then elaborates on (10) "Devadatta is a lion" to explain how metaphors work in relationship to denotation as well as how hearers understand what is meant. He argues that both "Devadatta" and "lion" are used literally, in an important sense. From the denotation of a primary meaning (here, LIONHOOD), certain qualities are understood. These qualities include such things like courage. We then understand that these qualities are also found in Devadatta.

But how does someone hearing this sentence know it is not literal? Kumārila describes the process of comprehension this way:

And as soon as the word 'lion' has been uttered, the persons addressed directly comprehend it, not as having its denotation imposed on any other object; and then it is that, finding this direct denotation to be otherwise inexplicable with its avowed coextensiveness with Devadatta, for example, they conclude to take the word 'lion,' for example, in its indirect or figurative sense. And in this it is clear that the persons addressed comprehend this figurative meaning only through similarity, without having imposed the character of the lion upon Devadatta. ${ }^{26}$

In other words, the trigger is the inexplicability otherwise (anyatha-anupapatti) of "Devadatta" and "lion" referring to the same thing, directly. For instance, armed with the background knowledge that "Devadatta" refers to a human being, rather than a lion in a zoo, we are unable to understand the utterance unless we take it metaphorically. According to Kumārila, its meaning is determined by the properties which the universal LIONHOOD has, in virtue of its inhering in a particular lion qualified by courage, etc., as these are then the properties which Devadatta also has.

As noted earlier, this case involves indicated qualities. "Lion" would ordinarily refer to the universal LIONHOOD, and here it plausibly should be taken in a generic sense. However, since human beings are not lions, there must be another explanation for the attempted predication. This is another dissimilarity with the metonymical reference cases. Whereas those cases require coercion for compositional reasons, this case is compositionally adequate but appears to be false. We are faced with the background principle that we should find an at least plausibly true interpretation. While Kumārila is clear to distinguish understanding an utterance and evaluating whether it is true, here we look for an interpretation which, whether we finally conclude it is true, can be prima facie true. It is not patent nonsense. The route for this interpretation again follows the structure embedded within our knowledge of the meaning of "lion." Here, rather than the particular lion being indicated in order to repair the sentence, we have the qualities of a lion being indicated, in particular, those which are similar to Devadatta. Kumārila notes that we use metaphor when we do not want to explicitly assert all of the ways in which Devadatta is like a lion. This cluster of qualities, however complex, is what is understood by the hearer.

Up until this point, however, verbal postulation has had as its content a single expression (whether a sentence, phrase, or word) in the paradigmatic cases. In contrast, we might think metaphors are open-ended. Kumārila observes that since metaphorical interpretation is central to encouraging us to act according to Vedic injunctions, it needs to be in some way stable. There can be no vagueness in the secondary or non-literal interpretation, since it is made recourse to in order to understand the full discourse unit in cases which are otherwise inexplicable, and the Vedic texts are taken to be a source of knowledge. Further, the Mīmāmsā wish to explain utterances as much as possible without recourse to speaker intention or human psychology (they

Journal of World Philosophies 2 (Summer 2017): 67-80 
appeal to this intention for ordinary speech, but not for Vedic language). ${ }^{27}$ The desire to explain metaphorical meaning in virtue of contextual principles and stereotyped association is not unique to the Mìmāmsāa, but is grounded in the recognition that linguistically competent people are able to interpret metaphors rapidly in a variety of contexts.

So one way to explain how metaphor works in this manner is to conclude that, since people are able to understand a figurative meaning, it cannot simply be an open-ended list of properties. That is, unlike what Donald Davidson claims - that there is "no end to what we can say" about what a metaphor means, Kumārila is committed to the view that there is..$^{28}$ While he admits that there is no single word which would denote all of these properties, there is an end to them, since we have a sense of what the properties are. There are certain essential characteristics to being a lion which are the focus of the metaphor and which are restricted by similarity with the metaphorical target, and based upon the ordinary use of words. Thus verbal postulation could conceivably generate a meaning which, though complex, is comprehensible and determinate.

In conclusion, applying the general schema of postulation to the lion metaphor, we would have:

Verbal Postulation in the Case of "Lion"

'Devadatta has some of the qualities of a lion' is postulated from 'Devadatta is a lion' and the requirement that sentences must be plausibly true iff:

1. ' $p$ ' is a utterance known via testimony and $m$ is an already-established fact

2. The presumption of 'Devadatta has the qualities of a lion' is required to make 'Devadatta is a lion' compatible with the requirement that sentences must be plausibly true.

Thus, I conclude that given the inexplicability of "lion" unless it is taken metaphorically, on Kumārila's view we should be said to postulate a metaphorical interpretation. This is verbal postulation because the conclusion—-the figurative sense of lion—is derived via inexplicability otherwise, recourse to linguistic norms, and conceptual structures. As with his discussion of metonymy, that postulation is driving interpretation is left implicit. However, analogous interpretive processes grounded in ascertaining the necessary solution to an apparent incomprehensibility drive both.

\section{$5 \quad$ Conclusion: Linguistic Interpretation as Knowledge}

I have argued that, on Kumārila's view, both metonymy and metaphor involve a kind of postulatory reasoning which resolves interpretive tension by positing new meanings. This may happen either by metonymically inserting a new meaning within the sentence or by a new meaning being implicated, beyond the ordinary sentence meaning. Further, the composition of sentence meaning is, in many cases, also metonymically driven, on Kumārila's analysis. Since verbal postulation results in a piece of knowledge, this entails that the results of linguistic interpretation, when it involves verbal postulation, can constitute knowledge.

Now, as Guha (2015) has pointed out, it is possible to use methods of linguistic interpretation other than verbal postulation. Kumārila appeals to convention at certain points, which can act as a short-cut for reasoning. In terms of sentence composition, verbal postulation qua metonymy is involved only in cases where shifts in meaning are necessary — say from a universal to a particular—but perhaps not in all cases (though this is a point of ambiguity on this subject in early texts, like Kumārila's). Thus while perhaps not all metaphors are interpreted through verbal postulation, the Mìmāmsā analysis underscores that we can interpret metaphor using verbal postulation and that these metaphors can be used in truth-conducive manners.

Journal of World Philosophies 2 (Summer 2017): 67-80 
For instance, this paper's opening metaphor,

(1) 'That cup is the starting-bell to my day' could be uttered at a coffee shop, after I've told the barista

(11) Make that espresso a double to wake me up.

With this metaphor, I have encouraged the barista to perform her action by pointing out the effect of the espresso, through its similarities to an opening bell for a busy trading day. This exhortation, like Kumārila's (4) "The grass-bed is the ritual patron," augments an instruction, and this instructional context constrains the resolution.

Verbal Postulation in the Case of "Coffee"

'That [coffee contained in the cup] has the qualities of a starting-bell' is postulated from 'That cup is the starting-bell to my day' and norms of linguistic communication iff:

1. 'That cup is the starting-bell to my day' is a utterance known via testimony and the requirement that sentences must be unified meaningful entities is an already-established fact

2. The presumption of 'That [coffee contained in the cup] has the qualities of a starting-bell' is required to make 'That cup is the starting-bell to my day' compatible with the requirement that sentences must be unified meaningful entities.

Kumārila's discussion of so-called figurative language in relationship to verbal postulation occurs in two contexts: cases where we must use metonymy to constitute a syntactically and semantically unified sentence meaning, and cases where metaphors are uttered to exhort ritual practitioners to engage in certain actions. Both of these contexts underscore the way in which figures of speech are not necessarily a matter of rhetorical flourish, but core elements of verbal communication. Metonymy is frequently a result of compositional coercion, and metaphorical meaning the outcome of contextually-constrained similarities.

In particular, in the case of the exhortative sentence, where there is a functional equivalence between the grass-bed and the ritual patron, what kinds of similarities are understood is dependent upon the sentence context. For instance, that the ritual patron is, like a woven grass-bedding, constituted of smaller parts combined to make a whole, is a similarity which gives a reason for offering the entirety of the grass-bedding into the fire. The fire (elsewhere metaphorically identified with heaven) burns up all of the grass-bedding, in a way which underscores that the entirety of the ritual patron should be carried to heaven.

Both metonymy and metaphor, through verbal postulation, are related to primary word meanings, in Kumārila's view. This enables linguistic interpretation to be constrained and, at least in some contexts, to result in knowledge. Here, I would differ slightly with Gerow, whose reflections on Jakobson I opened with. He notes that the Mīmāmsakas distinguish between similarity (the basis of metaphor) and other genuine relationships, such that similarity is not objective, unlike association or cause-and-effect which drive metonymy. While we have seen there are some problems with the similarity relationship in Kumārila—its metaphorical nature, for instance-I think that insofar as metaphors are understood by verbal postulation, there is room for more objectivity. After all, Kumārila does note that similarity, the relationship which is also crucial for analogical reasoning (upamana), is not entirely dependent on an agent's determination. The similarity between the lion and Devadatta in the metaphor we have examined is due to properties in the universal class. It is a genuine relation which is recognized by our faculties, and about which we can be mistaken (Jha 2009).

The relationship between analogy and metaphor, and the role of similarity in both, are other topics on which the Mīmāṃsakas have much to say, and which are worth further exploration. Further, it is now wellestablished that Mīmāṃsā thought forms the conceptual groundwork for later, increasingly sophisticated,

Journal of World Philosophies 2 (Summer 2017): 67-80 
analysis of poetic language and linguistic comprehension in Sanskrit, giving another reason for closer examination of their efforts. While the remarks above can only be an initial foray into complexities of the epistemology of non-literal speech in Kumārila's work, they do demonstrate the Mīmāṃsā commitment to, and the plausibility of, rational principles which constrain linguistic interpretation and raise it to the level of knowledge. ${ }^{29}$

Malcolm Keating is Assistant Professor of Philosophy at Yale-NUS College. His research is in philosophy of language in the classical Indian and broadly Anglophone analytic traditions.

1 Roman Jakobson, “The Metaphoric and Metonymic Poles," in Fundamentals of Language Number 2, ed. R. Jakobson and M. Halle (The Hague/Paris, Mouton, 1971), 90-6.

2 Edwin Gerow, "Escaping Language: Roman Jakobson and Abhinavagupta," Journal of the American Oriental Society 130, no.1, (2010): 23-34.

3 Kumārila Bhațța is the progenitor of a line of thinkers who come to be known as the "Bhātța Mīmāṃsā," in contrast to another set of Mīmāṃsā thinkers, the Prābhākara Mīmāṃsā. The distinction between them is nuanced and need not concern us here. An introduction to Kumārila and Mīmāmsāā linguistic thought more generally can be found in the following references: Franklin Edgerton, "Some Linguistic Notes on the Mīmāṇsā [sic] System,” Language (1928): 171-77; Elisa Freschi, Duty, Language and Exegesis in Prábhäkara Mimāmsa (Leiden: Brill, 2012); Lawrence McCrea, The Teleology of Poetics in Medieval Kashmir (Cambridge: Harvard University Press, 2008); Andrew Ollett, "What is Bhāvanā?" Journal of Indian Pbilosophy, no. 41, (2013): 221-62; John Taber, "The Theory of the Sentence in Purva Mīmāmsāa and Western Philosophy," Journal of Indian Philosophy, no. 17, (1989): 407-30, Jean-Marie Verpooten, Mimāmsa Literature, vol. 6 of A History of Indian Literature (Wiesbaden: Otto Harrassowitz, 1987).

$4 \quad$ For a selection of sources treating this topic see ed. Antonio Barcelona, Metaphor and Metonymy at the Crossroads: A Cognitive Perspective (Berlin: Mouton de Gruyter, 2003); ed. René Dirven and Ralf Pörings, Metaphor and Metonymy in Comparison and Contrast (Mouton \& de Gruyter, 2002); Dedre Gentner and Brian Bowdle, "Metaphor as Structure-Mapping," in The Cambridge Handbook of Metaphor and Thought, ed. R. Gibbs (New York, Cambridge University Press, 2008), 109-28. Roman Jakobson, "The Metaphoric and Metonymic Poles," in Fundamentals of Language Number 2, ed. R. Jakobson and M. Halle, (The Hague/Paris, Mouton, 1971), 90-6; and Ofra Magidor, "Category Mistakes and Figurative Language," Philosophical Studies (2015): 1-14.

5 The Sanskrit terms for what I will call "metonymy" and "metaphor" are laksanā and gauna-vrtti, usually translated as "indication" and "qualitative meaning" (or a meaning due to qualities, guna). There are questions about how to draw the boundaries between metonymy and metaphor, and whether these terms precisely match the phenomena picked out by laksana and gauna-vrtti. For the sake of simplicity, I use the familiar English terms, noting that they are being used to pick out whatever phenomena Kumārila is discussing through his examples.

Journal of World Philosophies 2 (Summer 2017): 67-80 
Important literature on verbal postulation and metonymy includes D.M. Datta, "Postulation (arthäpatti)" in The Six Ways of Knowing (Calcutta, University of Calcutta, 1932/1997), 199-206; Nilanjan Das, "laksanāa as Inference," Journal of Indian Philosopby 39, no. 4-5, (2011): 353-66; Nirmalya Guha, "Lakșan̄ā as a Creative Function of Language," Journal of Indian Philosophy, 40, no. 5, (2012): 489-509; Nirmalya Guha, "On arthäpatti," Journal of Indian Philosophy 44, no. 4, (2016): 757-76; Tulsi Ram Kanaujia, "Heterogeneity of arthapatti," in Philosophy, Grammar, and Indology: Essays in Honour of Professor Gustav Roth, ed. H. S. Prasad, and Gustav Roth (Delhi: Indian Books Centre, 1992), 165-84; K.K. Raja, "Aksepa, arthapatti and laksanā," in Cultura Indica: Tributes to an Indologist Professor Dr. Asoke Chatterjee Sastri, ed. Viśvanātha Devásarmā et al (Delhi: Sarada Publishing House, 1994), 103-06; and Kiyotaka Yoshimizu, "Kumārila's Propositional Derivation (arthapatti) without Pervasion (vyäpti)," in Expanding and Merging Horizons: Contributions to South Asian and Cross-Cultural Studies in Commemoration of Wilhelm Halbfass (Wien: Verlag der Österreichischen Akademie der Wissenschaften, 2007), 315-35. I omit entirely the important discussion about whether postulation is reducible to inference (anumana) for the sake of space.

7 arthapattir api drstah 'sruto vā artho 'nyathā nôpapadyata ity artha-kalpaña. SV 5.8, Ganganatha Jha, Slokavarttikam of Kumarila Bhatta with the Commentary Nyayaratnäkara of S'̈ri Parthasarathi Misra, vol. 1, 2, 3 of Chaukhamba Indological Studies (Delhi: Chaukhamba Sanskrit Pratishthan 2009), 595. Unless otherwise noted, translations are mine.

8 For the sake of space, I do not treat the relationship between the two varieties of postulation. Opponents of Kumārila's analysis, the Prābhākara, argue that this distinction is specious, and that putatively verbal postulation is no different than experiential (drstah) postulation.

atah'srutasya vakeyasya yad-artha-pratipädanam tad-ätma-Tabha eva syäd vinä nêty etad isyate. SV 5.8.76, Jha (2009, 621).

pinatva-bhojana-pratisedhayor eka-vakeyatva-anupapattyä tad-upapädañaya tac-chesatvena ratri-väkyam kalpyata iti. Părthasārathimiśra's commentary on SV 5.8.76, Jha (2009, 621). The idea of eka-vakeyata, or the unity of sentence meaning, is central for Mīmāmsā hermeneutics. In every sentence (vakkya), there must be only one primary word-meaning, and all other word-meanings must be related to it, as qualifiers. This principle drives interpretation, where readings which flout this rule are faulty. In this case, as McCrea (2008, 75, fn 38) points out, echoing Kumārila's comments in the following verses, the sentence given through postulation is not part of the testimonially-understood sentence. This sentence is constituted by the ordinary meanings of the words, in combination-and this is the end to the functional role of the pramana of testimony. Postulation is distinct from testimony.

11 Despite general agreement that metonymy functions through verbal postulation (see Bimal Krishna Matilal, The Word and the World [Oxford: Oxford University Press, 2010], 110, and McCrea [2008, 756], for example) there has been some recent dispute over whether this is the case (see Das 2011; Guha 2012, Guha 2015, and Malcolm Keating, "Mukulabhatta’s Defense of Laksaña: How We Use Words to Mean Something Else, But Not Everything Else," Journal of Indian Philosophy 41, no. 4, [2013]: 439_ 61). More historical work to understand how different Indian philosophers understand verbal postulation is necessary.

12 Remembrance, or smrti, is not a pramana, although it is implicated in the process of learning and subsequently recalling the objects associated with words. Memory of these objects is not equivalent to word-meaning, however. 
13 The favored term for "universal class property" is akrti and while the use of this term in earlier Mīmāṃsā is subject to significant dispute (for a summary see Madhav Deshpande, The Meaning of Nouns: Semantic Theory in Classical and Medieval India, Delhi: D.K. Printworld, 2003.) In Kumārila's work, the term does not refer to a shape or structural configuration, but to a property which differentiates an object from other objects, and in virtue of which collection of individuals is grouped into a class. The examples usually given are animals, natural elements, and the like.

14 Wade T. Wheelock, "Patterns of Mantra Use in a Vedic Ritual," Numen 32, no. 32, (1985): 169-93.

15 abbidheya-avina-bbüte pravrttir laksaña isyate laksyamana-gunair yogäad vrtter ișta tu gaunată. TV 1.4.11-17, in Kumārilabhațta, Tantravarttika, 318 (Benares: Braj B Das and Co, 1892-1903).

16 yathá eva äkrti-vacanah'sabdas tat-saha-caritam. vyaktim laksyati tathaiva yaști-mañca-ásva-ädayas tatsambaddhapurusa-laksañä-arthā bhavanti. Kumārilabhațta (1892-1903, 318).

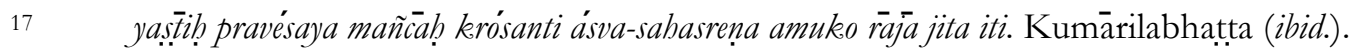

18 Malcolm Keating, “The Cow is to Be Tied Up: Sort-shifting in Classical Indian Philosophy," History of Philosophy Quarterly 30, no. 4, (2013): 311-32.

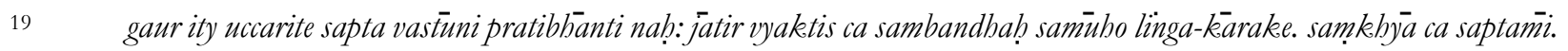
Kumärilabhatta $(1892-1903,318)$. The term karaka, which could be glossed "a connection to an action,", refers to the particular classification that an object is given in relationship to an action. For example, an object may be an agent of an action or the subject of an action. These karaka classifications are not to be confused with grammatical cases. For more details, see George Cardona, "Pānininis Kārakas: Agency, Animation and Identity," Journal of Indian Philosophy 2 (1974): 231-306 and Madhav Deshpande, "Prototypes in Pạninian Syntax," Journal of the American Oriental Society 111, no. 3, (1991): 465-80.

20 Peter Scharf, The Denotations of Generic Terms in Ancient Indian Philosophy: Grammar, Nyaya, and Mimämsa, Transactions of the American Philosophical Society 86, no. 3, (1996). See pp. $229 \mathrm{ff}$.

21 There is no explicit appeal to a universal class property in the discussion of staffs. However, in TV I.III.10, there is a mention of pots being a class of things which, presumably, would be marked by its having a distinguishing or universal property, so probably Kumārila would wish to say that "staffs" would refer to a universal staffhood. At the same time, since Kumāila explicitly rejects the idea that the term $\bar{a}$ krti (universal class property) refers to a shape, this leaves some tension in the account of universals, since it would seem that there is an important distinction, made by later philosophers, between classes grouped naturally and classes grouped by pragmatic aims.

22 Kumārilabhațta $(1892-1903,318)$.

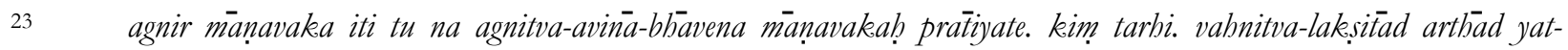
paingalya-ädi gamyate. tena mānavake buddhị̆ sàdṛ́syäd upajayate. Kumārilabhațta (1892-1903, 318).

24 eka-kapälavat sükta-väkena prastaram prabarati iti yajamane prabriyamäne sarva-tantra-vilopaprasangah. "With the recitation of a Vedic hymn, like the single sacrificial bowl, the ritual grass-bed is thrown (into the fire)-therefore, when the ritual patron is being thrown (into the fire), there would be the negative consequence of a break in the entire procedure.” Kumärilabhatta (1892-1903, 319).

25 I thank Amber Carpenter, Thomas Doctor, and Gavin Flood for discussion of this metaphor at the Ancient Worlds Workgroup at Yale-NUS College. This workgroup is funded by the Singapore Ministry of Education's AcRF Tier 1 funding support and Yale-NUS College, with grant number IG16-RCS002.

Journal of World Philosophies 2 (Summer 2017): 67-80

Copyright $\subset 2017$ Malcolm Keating.

e-ISSN: 2474-1795 • http://scholarworks.iu.edu/iupjournals/index.php/jwp• doi: 10.2979/jourworlphil.2.1.06 
26 sarvathā tavad ayam. gauna-mukhya-vibhagahạ śroț̣nam artha-visesa-avadhärane vyāpriyate te ca padavelayam anadbyäropita-sva-artha-vrt_t ty eva simba-ädi-padam adbyavasaya devadatta-ädi-pada-samānaadhikaranya-anyathaanupapattyā gaunatām. kalpayanti tatra ca eșam. svayam anaropya eva sim. hatvam prayogah. Kumārilabhațta (18921903, 321-22).

27 This explanatory burden is due in part to the view that the Vedas are apauruseya, or without an author. For details on this, see the earlier cited literature on Mīmāmsā.

28 Donald Davidson, "What Metaphors Mean," Critical Inquiry 5, no. 1, (1978): 31-47.

29 I would like to thank the anonymous reviewers at Journal of World Philosophies for their valuable feedback, as well as Laura Guerrero for her comments on revisions, and Gavin Flood for reading portions of the Tantra-varttika with me. 